\title{
Vitamin D and critical illness: what endocrinology can learn from intensive care and vice versa
}

\author{
K Amrein ${ }^{1,2}$, A Papinutti ${ }^{3}$, E Mathew ${ }^{3,4}$, G Vila ${ }^{5}$ and D Parekh ${ }^{6}$ \\ ${ }^{1}$ Thyroid Endocrinology Osteoporosis Institute Dobnig, Graz, Austria \\ ${ }^{2}$ Division of Endocrinology and Diabetology, Department of Internal Medicine, Medical University of Graz, Graz, Austria \\ ${ }^{3}$ Department of General Surgery, Medical University of Graz, Graz, Austria \\ ${ }^{4}$ Department of General Surgery, St. Elisabeth's Hospital, Graz, Austria \\ ${ }^{5}$ Division of Endocrinology and Metabolism, Department of Internal Medicine III, Medical University of Vienna, Vienna, Austria \\ ${ }^{6}$ Clinician Scientist in Critical Care, Birmingham, Acute Care Research Group, Institute of Inflammation and Ageing, University of Birmingham, \\ Birmingham, UK
}

Correspondence should be addressed to K Amrein: karin.amrein@medunigraz.at

\begin{abstract}
The prevalence of vitamin $D$ deficiency in intensive care units ranges typically between 40 and $70 \%$. There are many reasons for being or becoming deficient in the ICU. Hepatic, parathyroid and renal dysfunction additionally increases the risk for developing vitamin D deficiency. Moreover, therapeutic interventions like fluid resuscitation, dialysis, surgery, extracorporeal membrane oxygenation, cardiopulmonary bypass and plasma exchange may significantly reduce vitamin D levels. Many observational studies have consistently shown an association between low vitamin D levels and poor clinical outcomes in critically ill adults and children, including excess mortality and morbidity such as acute kidney injury, acute respiratory failure, duration of mechanical ventilation and sepsis. It is biologically plausible that vitamin D deficiency is an important and modifiable contributor to poor prognosis during and after critical illness. Although vitamin D supplementation is inexpensive, simple and has an excellent safety profile, testing for and treating vitamin D deficiency is currently not routinely performed. Overall, less than 800 patients have been included in RCTs worldwide, but the available data suggest that high-dose vitamin D supplementation could be beneficial. Two large RCTs in Europe and the United States, together aiming to recruit $>5000$ patients, have started in 2017, and will greatly improve our knowledge in this field. This review aims to summarize current knowledge in this interdisciplinary topic and give an outlook on its highly dynamic future.
\end{abstract}

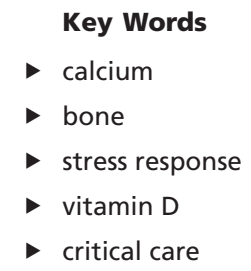

Endocrine Connections (2018) 7, R304-R315

\section{A short history of vitamin D in critical care}

Only 10 years ago, a potential link between acute illness and vitamin $\mathrm{D}$, which is well known for its role in calcium and bone homeostasis, was regarded as quite absurd - how could this hormone be acutely relevant to the specialty of critical care? In fact, it now transpires that the high prevalence of vitamin D deficiency in critically ill adults and children, combined with the pleiotropic effects of vitamin $\mathrm{D}$, could indeed be of great importance in this patient population.

The first relevant randomized controlled trial was published in 2003 by the Belgian endocrinologyanesthesiology visionary Greet van den Berge and her
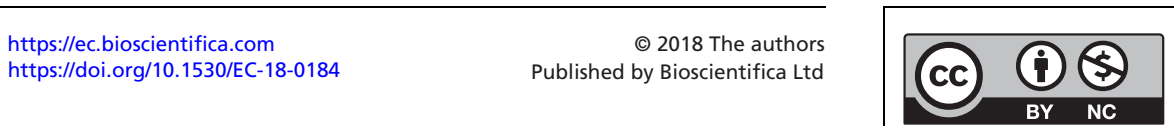

This work is licensed under a Creative Commons Attribution-NonCommercial 4.0 International License. 
team. In this trial, a 'low' dose of 200 IU of vitamin D3 compared with a 'high' dose of 500IU over 10 days in 22 prolonged critically ill patients showed limited effects on inflammatory biomarkers (1). Although, in retrospect, the 'high dose' of vitamin D was quite low, this trial was ahead of its time and led the way revealing important findings of severe bone hyper-resorption and presence of vitamin D deficiency in the critically ill.

A few years of silence in the scientific community followed, but the topic rapidly regained attention after the publication of two studies in 2009: the report of high rates of vitamin $\mathrm{D}$ deficiency including some with undetectable levels among 42 Australian critically ill patients referred to the endocrinology department in a letter in the New England Journal of Medicine (2) and 100 children requiring ICU admission for respiratory infections by Canadian researchers (3). This was to be the beginning of subsequent years of research and debate with skeptics arguing that deficiency is purely a bystander and marker of illness severity. Despite this, the current evidence for replacement therapy is compelling, but there remain unanswered questions, including adequate dosing strategies, the effect of critical illness on vitamin D metabolomics and the optimum target vitamin $\mathrm{D}$ level to provide clinical benefit in critical illness.

\section{Vitamin D status in critically ill patients}

Vitamin D deficiency is common in critical illness with prevalence between 40 and 70\% (Table 1) $(4,5,6,7)$. In burn patients, the prevalence appears to be even higher

Table 1 Selected observational trials on the incidence of vitamin D deficiency in ICU patients.

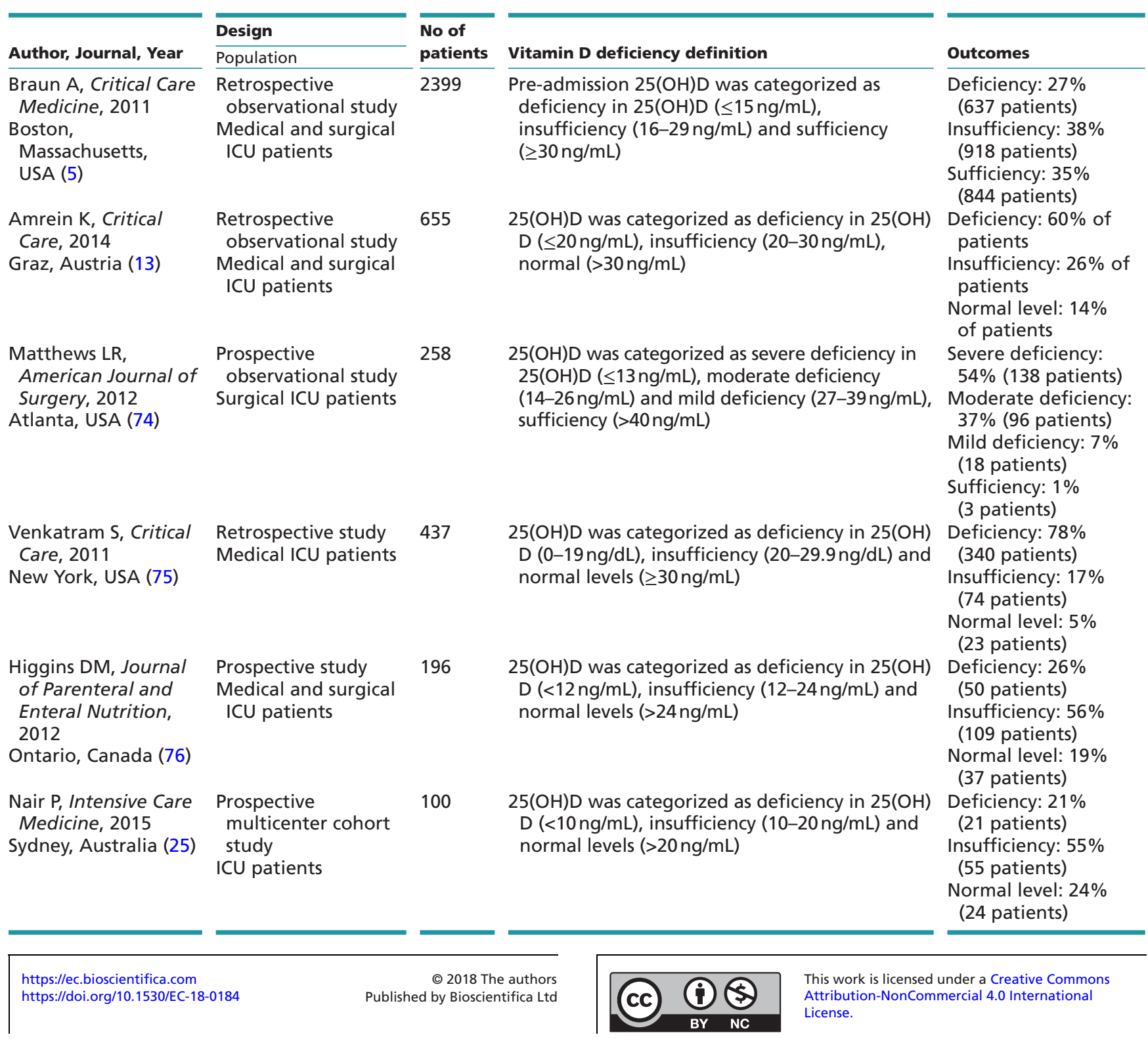


$(8,9)$. Many patients enter the ICU in a deficient state due to pre-existing malnutrition and disease. However, vitamin D metabolism is dysregulated in some critically ill patients with vitamin D levels rapidly falling after ICU admission $(10,11)$. The similarity between results in diverse geographical areas with variable UVB exposure suggests that the influence of individual chronic and/or acute disease on vitamin D deficiency is largely independent of sun exposure (12). A number of large observational studies from across the globe have confirmed that vitamin D deficiency (usually defined as $25(\mathrm{OH}) \mathrm{D}$ levels below $20 \mathrm{ng} / \mathrm{mL}$ ) is frequent in adult and pediatric critical illness $(5,6,13,14,15,16)$. Vitamin D deficiency has been shown to be associated with sepsis, acute respiratory distress syndrome and acute kidney injury $(17,18,19,20)$ and three different meta-analyses confirm that patients with low vitamin D status have a longer ICU stay and increased morbidity and mortality $(18,21,22)$. Recently, substantial metabolomic differences in pathways related to glutathione metabolism and glutamate metabolism were found in an observational study in vitamin $\mathrm{D}$ deficient compared to non-deficient ICU patients (separated by a cutoff of $15 \mathrm{ng} / \mathrm{mL}$ ) (23).

In critical illness, there also is evidence of rapid falls in circulating $25(\mathrm{OH}) \mathrm{D}$ concentrations, potentially due to disrupted metabolism, fluid resuscitation, decreased synthesis of vitamin D-binding protein due to hepatic dysfunction, interstitial extravasation caused by increased vascular permeability, renal wasting of vitamin $D$, decreased renal conversion to $1,25(\mathrm{OH}) \mathrm{D} 3$ and increased tissue conversion of 25(OH)D3 to 1,25(OH)D3 $(11,24,25$, 26). The role of free/bioavailable vitamin $D$ remains unclear although it is possible that although vitamin $\mathrm{D}$ binding protein (VDBP) and thus total D decreases, circulating free D may be maintained (27). In a post hoc analysis of the VITDAL-ICU trial, free/bioavailable vitamin D was not superior to total $25(\mathrm{OH}) \mathrm{D}$ in predicting mortality neither in the placebo nor in the intervention group (28). There is also evidence that critically ill patients with very low 25(OH)D concentrations have blunted responses to vitamin $\mathrm{D}$ replacement possibly due to conversion into alternate metabolites and epiforms (29).

\section{Biological rationale}

There is strong biological plausibility that supports a contributing role of vitamin $\mathrm{D}$ deficiency to poor outcomes, mediated by genomic and non-genomic effects (8). In the last decade, vitamin D has been implicated in the function of a wide range of tissues including the innate and adaptive immune system $(30,31)$. The specific nuclear vitamin D receptor (VDR) is widely expressed in many cell types and organs relevant to critically illness (32) and is known to regulate hundreds of genes $(32,33)$. Therefore, vitamin $\mathrm{D}$ has the ability to act synergistically on the immune response to acute systemic inflammation and infection $(19,34)$, lung epithelial function (35), muscle function and metabolism (36) and cardiac function (37), to name a few (Fig. 1). Additional information on exact mechanism of action and potential influence of vitamin $\mathrm{D}$ deficiency on acute critical illness is summarized in Table 2.

Vitamin D, rather than a vitamin or just a food supplement, is therefore in reality, a precursor to a potent steroid hormone influencing a wide range of cellular pathways in organs that are highly relevant to the effects of critical illness and may exert its beneficial effects on acute inflammation, nosocomial infection, respiratory failure, cardiogenic shock and critical illness myopathy. In summary, vitamin D may help to prevent secondary complications in a population at very high risk and there is currently no rationale to suggest that, apart from vitamin D deficiency, any particular type of ICU patients could benefit more or less. However, burn patients appear to be at particular and even long-term risk because of the necessary sun avoidance after their injury $(8,9)$.

\section{Bone during and after critical illness}

Recently, bone health has been recognized as important for ICU survivors and the limited available data suggest impaired bone health and high fracture risk (38, 39, 40, 41). In addition to underlying disease, critical illness per se seems to be detrimental to musculoskeletal health in various ways: immobilization, inflammation, multiple endocrine alterations, hypercatabolism including muscle wasting, malnutrition and some drugs all have the potential to disturb the delicate balance between bone formation and resorption $(42,43)$. In a post hoc analysis of the VITdAL-ICU study, vitamin D3 did not have a significant effect on the increased levels of $\beta$-Crosslaps and osteocalcin during critical illness (44). Nevertheless, vitamin $\mathrm{D}$ is one of the cornerstones of osteoporosis therapy. Treatment of vitamin D deficiency with the aim to reach levels considered necessary for optimal bone health in other populations (above $20 \mathrm{ng} / \mathrm{mL})(45,46)$ may possibly be the only easily adoptable treatment to improve skeletal consequences of prolonged critical

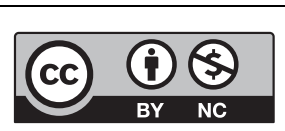

This work is licensed under a Creative Commons Attribution-NonCommercial 4.0 International License. 


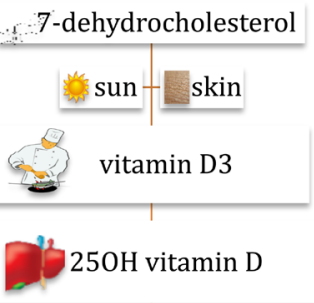

autocrine effects (most tissues) -
intracellular 1,25(OH)2 Vitamin D
excessive bone loss

illness besides other, more expensive, risky and/or timeconsuming possibilities like antiresorptive treatment and physiotherapy. Hollander and Mechanick suggested the consideration of intravenous bisphosphonates which potently reduce bone resorption (47). However, a number of contraindications and potential side effects like hypocalcemia, renal impairment and atrial fibrillation need to be considered. In order to avoid frank hypocalcemia, vitamin D deficiency should always be treated before bisphosphonates are given. Interestingly, in a large retrospective analysis, patients pretreated with bisphosphonates had significantly better outcomes even though they were older; additional vitamin D seemed to have an additional beneficial effect (48). In summary, ICU survivors appear to be at high risk for excessive bone loss and fracture risk. Therefore, interventional studies with vitamin $\mathrm{D}$ and antiresorptive agents including denosumab and parenteral bisphosphonates are necessary in the near future.

\section{Effects of enterally administered vitamin D supplementation}

Van den Berghe et al. (1) tried to demonstrate that in critically ill patients an intravenous supplementation with 200 (low dose group) compared to 500 (high dose group) IU cholecalciferol results in elevated to normal vitamin D levels. Although higher levels of $25(\mathrm{OH}) \mathrm{D}$ were detected
Figure 1

Overview of vitamin D metabolism and its classic and non-classic effects on different target organs/ systems.

on days 2, 6 and 7 in the high-dose group compared to the low-dose group, they did not reach normal $25(\mathrm{OH})$ D levels.

Years later, Amrein et al. (49) initiated a randomized controlled pilot study with an ultra-high loading dose vitamin D (540,000 IU) in ICU patients. In this trial, 25 patients were randomly assigned to vitamin D3 versus placebo. The results showed significantly elevated $1,25(\mathrm{OH}) \mathrm{D}$ levels in the intervention group and in $80 \%$, normalized $25(\mathrm{OH}) \mathrm{D}$ levels were found. In consequence of these results, Amrein et al. (50) initiated the VITdAL-ICU trial, in which 475 ICU patients with vitamin D deficiency $(<20 \mathrm{ng} / \mathrm{mL})$ were randomly assigned to either high-dose vitamin D3 or placebo. The regimen of the high-dose group consisted of a single high-dose supplementation with 540,000IU followed by a 90,000IU monthly maintenance dose for five months. The $25(\mathrm{OH}) \mathrm{D}$ level in the high-dose group reached sufficiency $(>30 \mathrm{ng} / \mathrm{mL})$ in $52.2 \%$ of the patients after seven days.

Quraishi et al. (51) compared changes of $25(\mathrm{OH})$ $\mathrm{D}$ and cathelicidin levels in septic ICU patients. Thirty patients were randomly divided into three groups (each group consisting of 10 patients). The first group received 200,000 IU cholecalciferol enterally, the second 400,000 IU enterally and the third a placebo. Blood was drawn on days 1, 3, 5 and 7. Compared to baseline, the mean change in total $25(\mathrm{OH}) \mathrm{D}$ in the placebo group on day 5 was 3 (-3 to 8$) \%$, the $200,000 \mathrm{IU}$ cholecalciferol group https://ec.bioscientifica.com

https://doi.org/10.1530/EC-18-0184 (c) 2018 The authors Published by Bioscientifica Ltd
This work is licensed under a Creative Commons Attribution-NonCommercial 4.0 International License. 
Table 2 Mechanism of action on target organ systems that may influence critically ill patients.

\section{Target organs}

Immune system

\section{Mechanism of action}

Vitamin D metabolites are acting as modulators of cells of the innate and adaptive system $(30,31,34)$ Innate system: 1,25-dihydroxyvitamin D3 and 3 of its analogs induce expression of the human cathelicidin antimicrobal peptide (CAMP) gene and genes involved in autophagy and phagosome maturation all of which are involved in the intracellular destruction of pathogens; promotion of an anti-inflammatory response by inhibiting the maturation of DCs; Adaptive system: VitD induces anti-inflammatory responses through direct effects on T-cells $(34,77,78)$

Cardiac function Vitamin $D$ may play a role in atrial fibrilation prevention by negatively regulating the renin-angiotensinaldosterone-system (RAAS), mediating calcium homeostasis, binding to vitamin D receptors (VDR) on cardiac myocytes and furthermore by having antioxidant properties that may reduce levels of reactive oxygen species (ROS) in the atria, which contribute to inflammation and proarrhythmic substrate formation (79)

The exact mechanism of action unknown but the recent research on animal models suggest that calcitriol has been shown to have a key role in enabling the maturation and differentiation of ventricular myocytes isolated from neonatal rat hearts and could therefore potentially influence heart failure (37)

Vitamin D receptors are also present in all cells implicated in atherosclerosis. Those include endothelial cells, vascular smooth muscle cells and immune cells. It appears to regulate vascular cell growth, migration and differentiation; immune response modulation; cytokine expression; and inflammatory and fibrotic pathways. All of those mechanisms play a crucial role in different stages of the atherosclerotic plaque vulnerability and rupture (80)

Lung function

A lack of VDRs in the pulmonary epithelial barrier appeared to compromise its defense, leading to more severe lipopolysaccharide (LPS)-induced lung injury. Moreover, vitamin D treatment alleviated LPS-induced lung injury and preserved alveolar barrier function (35). Therefore, vitamin D may be a potential therapeutic strategy in acute lung injury and acute respiratory distress syndrome

Muscle function and metabolism

Bone
Some molecular mechanism studies suggest that vitamin D impacts muscle cell differentiation, intracellular calcium handling, and genomic activity. Some animal models have confirmed that vitamin D deficiency and congenital aberrations in the vitamin $D$ endocrine system may result in muscle weakness $(36,81,82)$ Limited available data in ICU survivors suggest impaired bone health and high fracture risk $(38,39,40$, $41,83) .1,25(\mathrm{OH})(2) \mathrm{D}(3)$ is known primarily as a regulator of calcium, but it also controls phosphate (re)absorption at the intestine and kidney. Mechanism of action involve 1,25(OH)2D3, FGF23 (fibroblast growth factor 23 - phosphaturic hormone produced in osteoblasts) and 1,25(OH)(2)D(3) via the PTH axis (84)
$49(30-82) \%$, and the 400,000 IU group in $69(55-106) \%$ $(P<0.001)$. The bioavailable $25(\mathrm{OH}) \mathrm{D}$ increased by 4 (-8 to 7$) \%, 45(40-70) \%$ and $96(58-136) \%(P<0.01)$.

Han et al. (52) administered cholecalciferol compared with placebo in a double-blind, randomized controlled pilot study in 30 patients. Nine mechanically ventilated ICU patients received 50,000 IU cholecalciferol on 5 days, 11 patients received $100,000 \mathrm{IU}$ daily and 10 patients were given a placebo. At baseline, 13 patients (43\%) had vitamin D deficiency $(25(\mathrm{OH}) \mathrm{D}<20 \mathrm{ng} / \mathrm{mL})$. The 50,000 IU and 100,000 IU regimens resulted in a significant increase in the average $25(\mathrm{OH}) \mathrm{D}$ plasma levels. On day 7 , the values were $45.7 \pm 19.6 \mathrm{ng} / \mathrm{mL}$ and $55.2 \pm 14.4 \mathrm{ng} / \mathrm{mL}$, respectively, compared to unchanged values in the placebo group $(21 \pm 11.2 \mathrm{ng} / \mathrm{mL}, P<0.001)$.

\section{Current vitamin D testing and supplementation in the ICU}

The most common laboratory test to assess vitamin D nutritional status is total 25-hydroxyvitamin D serum concentration. There are a number of methods for measuring 25-hydroxyvitamin D in serum or plasma, including enzyme immunoassay, radioimmunoassay, high-performance liquid chromatography (HPLC), liquid chromatography-mass spectrometry (LC/MS) and LC/MS/MS. Laboratory professionals are often confronted with challenges related to vitamin D testing, including controversy over optimal and target vitamin D concentrations, variable reference ranges across marketed assays and reference laboratories, lack of standardization of vitamin $\mathrm{D}$ assays and misordering of 1,25-dihydroxyvitamin D testing. Among possible markers, serum total $25(\mathrm{OH}) \mathrm{D}$ is currently considered to be the best marker of vitamin D status (53). Measurement of vitamin D concentration is currently not routine practice on ICU and there is currently no consensus on definition on vitamin D deficiency, in critical illness. The role of other metabolites including free/bioavailable vitamin D remains to be clarified. Generally, progress has been made in the last years in the harmonization of various assays. However, further standardization (e.g. the definition of vitamin $\mathrm{D}$ deficiency and measurement of other possible markers of vitamin D status) would be sensible (54). https://ec.bioscientifica.com

https://doi.org/10.1530/EC-18-0184
C) 2018 The authors Published by Bioscientifica Ltd

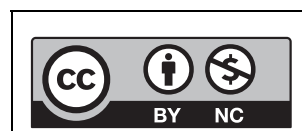

This work is licensed under a Creative Commons Attribution-NonCommercial 4.0 International License. 
In the general population, it is recommended that all healthy children and adults meet a daily minimum requirement of vitamin D - the Institute of Medicine (IOM) recommends $400-800$ IU of vitamin D3 (46). The Endocrine Society increased this dose to 1500-2000 IU/day for individuals at risk of deficiency $(45,55)$. Current standard enteral nutrition formulas used in critical illness contain vitamin D2 or D3 (native vitamin D, halflife 2-3 weeks), but rarely more than 400 IU in a daily regimen. Parenteral multivitamin preparations typically contain only 200 or 220 IU of native vitamin D. In healthy individuals, such doses can improve vitamin D deficiency, but this requires months of treatment. In critical illness, the optimal native vitamin $\mathrm{D}$ dose remains unclear. Although no standard of care has been established, it appears logical that at least the recommended daily allowances for healthy individuals should be provided (400-600 IU daily for children, 600-800 IU for adults). The role for additional provision of active vitamin D (calcitriol or other metabolites) is even less clear, but certainly needs to be further tested. Active and native vitamin D metabolites are very different in half-life (several hours compared to a few weeks), therapeutic range (narrow vs broad) and costs (more expensive vs inexpensive) (56). There is however a biological rationale that active vitamin $\mathrm{D}$ on top of high-dose vitamin D3 could be of additional benefit. Besides patients with chronic preexisting renal dysfunction, many other ICU patients appear to be unable to sufficiently activate native vitamin $\mathrm{D}$ to its physiologically active form calcitriol (50). To date, no trial has looked at a combined vitamin $\mathrm{D}$ regimen.

Circulating 25(OH)D concentrations may fall rapidly during the initial phase of severe acute illness and its treatment. Therefore, the use of a loading mega-dose for rapid restoration of vitamin $\mathrm{D}$ levels followed by regular supplementation appears necessary in critical illness (57). Apart from intramuscular high-dose vitamin $\mathrm{D}$ formulations, no intravenous vitamin D monopreparations are available at present.

\section{Side effects in critically ill patients}

Possible side effects after high dose supplementation include higher risk for fractures, falls and mild hypercalcemia. Symptoms are mostly related to the effects of hypercalcemia. Vitamin D intoxication can be caused by high intake ( $>50,000$ IU per day) and is typically linked to hypercalcemia and hyperphosphatemia. However, the intake of 10,000 IU vitamin D3 per day for up to 5 months is considered safe (58).
In ICU patients, side effects are rare and no vitamin $\mathrm{D}$ intoxication has been reported. However, due to the complexity of the treatment and the underlying disease, recognition of adverse events in a critically ill population is difficult. Several studies in ICU patients using mainly oral cholecalciferol in doses ranging from 200IU to $540,000 \mathrm{IU}$, reported very limited side effects $(1,50,51$, $59,60)$. In the VITDAL-ICU study, Amrein et al. (50) found mild hypercalcaemia in $1 \%$ of patients, all of which were asymptomatic. In this trial, overall no significant differences in calcium, phosphorus and renal parameters in either group were found. Vitamin D levels in the treatment group were well below the level considered acutely toxic $(150 \mathrm{ng} / \mathrm{mL})$ (2). While outside of the ICU mega-doses are now obsolete because of increased fracture and fall risk (61), available evidence in critical illness from the VITdAL-ICU trial do not suggest increased risk for falls or fractures in these specific circumstances (50). Vitamin D toxicity has not been described in the ICU setting but may occur after prolonged intake of excessive doses (>10,000 IU/day and 25(OH)D levels $>200 \mathrm{ng} / \mathrm{mL})$ and, rarely, in individuals with mutations in CYP24A1 causing failure to metabolize 1,25-dihydroxyvitamin D $(62,63)$. Additional information on available vitamin D formulations is given in Table 3 .

\section{What endocrinology can learn from intensive care and vice versa}

\section{Sample size and power of a study}

So far, many single vitamin D intervention trials have given disappointing results and many more, even relatively large trials including the recently completed VIDA and awaited VITAL trial are/will likely be negative (64). A great issue in these studies is that despite their relatively large size including thousands of individuals, they still are underpowered. Even more problematic, they have not exclusively included vitamin D-deficient subjects. It is not reasonable why patients with normal vitamin $\mathrm{D}$ levels are included in intervention trials; moreover, vitamin D should ideally not be given in the placebo group (65).

Recently, this concept was beautifully discussed in a German epidemiologic study showing that depending on the baseline risk of a population, the necessary sample size for a single trial to have adequate power increases sharply in low baseline risk (66). Therefore, the high prevalence of vitamin D deficiency and the inherently high morbidity and mortality in intensive care in a short time period increase the probability for an intervention trial to prove

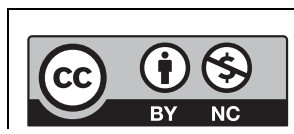

This work is licensed under a Creative Commons Attribution-NonCommercial 4.0 International License. 


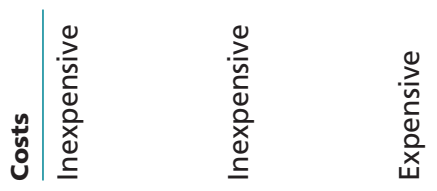

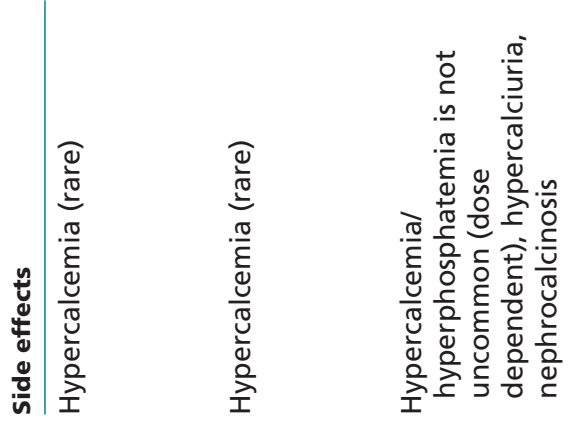

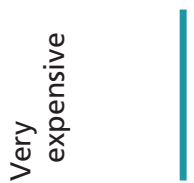

挡高

言要

บัำ ठั

बे

它

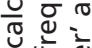

을

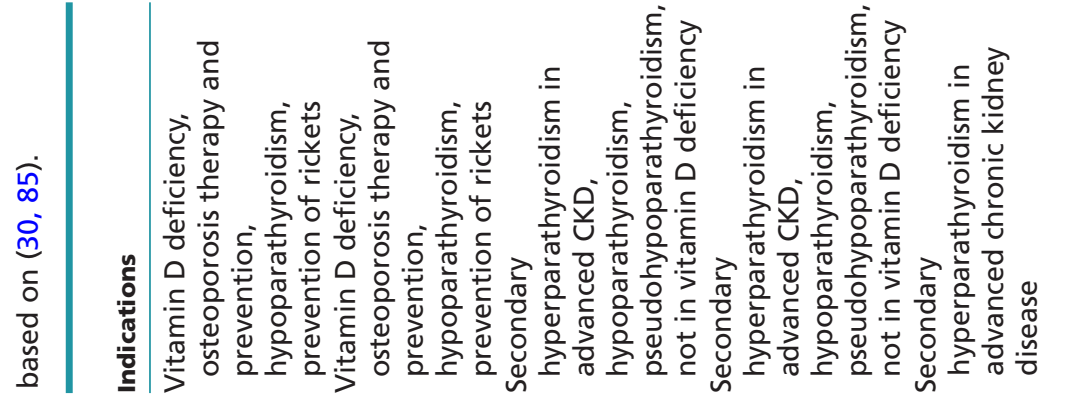

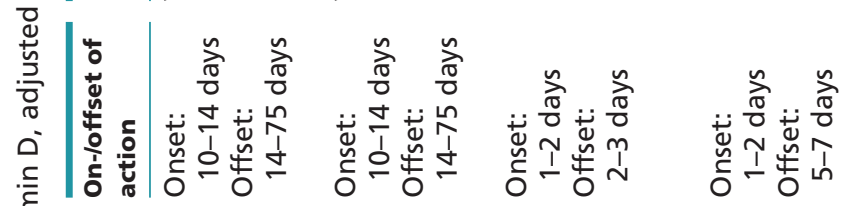

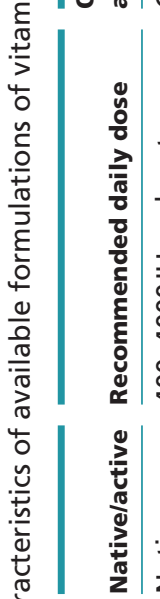

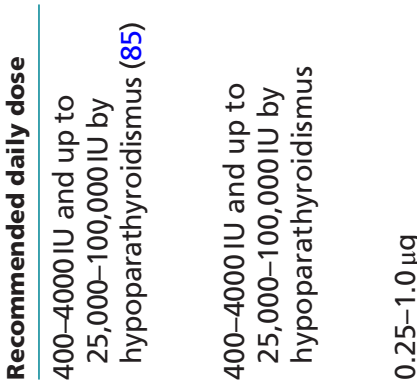

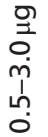

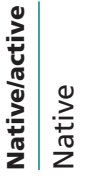

$\sum_{\substack{\pi \\ 2}}^{0}$<smiles>[Li][Ca]</smiles>

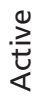

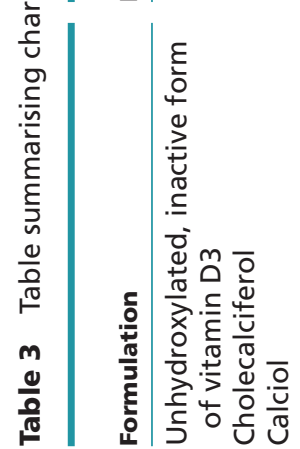

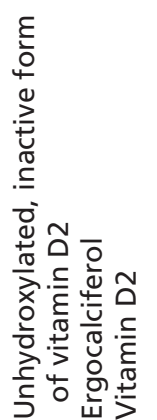

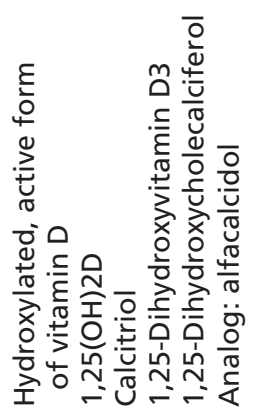

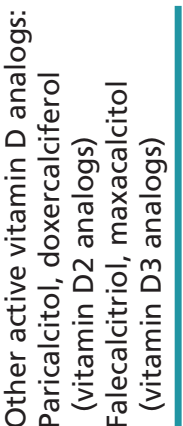


a beneficial effect of vitamin D. Therefore, we believe that currently, targeting high-risk groups and including exclusively patients with vitamin D deficiency will reduce necessary sample sizes and improve the likelihood of showing an effect.

\section{Megadoses}

To date, megadoses and long dosing intervals are considered obsolete. Besides higher risk of falls and/or fractures in multiple studies $(61,67)$, Martineau was also able to show a decreased efficacy of high bolus doses in the prevention of acute respiratory tract infections (68). This lack of effect appears biologically reasonable, as after a large dose, possibly vitamin $\mathrm{D}$ is catabolized more rapidly to inactive metabolites. Also, it is rarely necessary to increase vitamin D levels rapidly. However, in critical care, time is paramount, and vitamin D levels must be improved within days which is only possible with a megadose (57). Typical dosing regimens used in outpatients are ineffective in this short time period but a single, large vitamin D3 dose works within a few days (69). Therefore, the best approach in intensive care is probably a large loading dose followed by a regular daily or weekly maintenance dose. The optimal dosing regimen is likely also dependent on individual patient factors including gastrointestinal function, underlying disease, co-medication, renal/hepatic function, genetic factors, ethnicity and body weight. In critical care, it also makes sense to determine serial vitamin D levels to guide therapy in patients with prolonged ICU/hospital stay.

\section{Vitamin D intervention trials in critical illness}

In recent years, several vitamin D interventional trials with or without placebo groups including vitamin D-deficient individuals or all-comers have been completed (Table 4). Given the low chance of successful normalization of vitamin $\mathrm{D}$ status with the traditional daily vitamin $\mathrm{D}$ regimen (57), other supplementation strategies including mega-doses for initial loading have been used. Overall, there is substantial variation in these studies regarding treatment duration (single dose or up to 6 months), dose, route of administration (enteral, intramuscular or intravenous) and metabolite (native vitamin D: cholecalciferol, ergocalciferol, active vitamin D: calcitriol). With the exception of the VITdAL-ICU trial $(n=475)(50)$, these studies have been small $(n<70)$. In the VITdAL-ICU trial, there was a non-significant absolute risk reduction in 6-month all-cause mortality in the vitamin D group (placebo: $43 \%$ vs vitamin D3: 35\%). The findings did achieve statistical significance in the subgroup with severe vitamin $\mathrm{D}$ deficiency at baseline $(25(\mathrm{OH}) \mathrm{D}<12 \mathrm{ng} / \mathrm{mL})$ corresponding to a number needed to treat of 6 (50). The primary endpoint, length of hospital stay, however, was not different between groups.

Recently, three independent groups published metaanalyses on the effect of vitamin D on the mortality of ICU patients $(70,71,72)$. Because of the small number of additional patients besides the VITdAL-ICU trial, and the substantial heterogeneity between studies, these metaanalyses have added little additional information and maybe even caused confusion $(73,74)$. The conclusions drawn by the three groups of authors varied according to study selection; however, the fact that currently less than 800 adult patients have been included in published RCTs makes meta-analyses problematic at this stage. Furthermore, none of these trials specifically included critically ill patients with severe vitamin D deficiency, which is the only subgroup where a significant beneficial effect of vitamin D supplementation on mortality has been shown to date. Ironically, similar to other settings, vitamin D deficiency was not an inclusion criterion in some studies. Six trials are currently registered on clinicaltrials.gov examining the effect of vitamin D supplementation in critically ill patients with vitamin D deficiency. One is a phase 2 study in children (NCT02452762). Three trials involve small numbers of selected sub-groups of critically ill patients (e.g. acute kidney injury, NCT02962102, neuro-critical care, NCT02881957). A single-center study $(n=430)$ in Saudi Arabia is examining the effect of a single high dose $(400,000 \mathrm{IU})$ of vitamin D3 in critically ill patients with severe deficiency $(25(\mathrm{OH}) \mathrm{D}<12 \mathrm{ng} / \mathrm{mL})$ with a primary outcome of hospital mortality (NCT02868827). The last two are large multi-center randomized placebocontrolled trials that both have started in 2017 (summarized in Table 5) and will hopefully conclusively answer the question if vitamin D replacement confers clinical benefit in critical illness.

\section{Vitamin D intervention before critical illness}

In specific circumstances including intensive chemotherapy in some hemato-oncologic diseases, cardiac and other elective surgical procedures, ICU stay is foreseeable. Thus, we believe that diagnosing and treating vitamin D deficiency (besides iron and other nutritional deficiencies) appears reasonable in this subgroup, but there are currently no data to support such an approach.

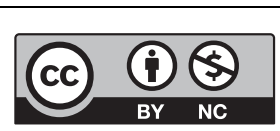

This work is licensed under a Creative Commons Attribution-NonCommercial 4.0 International License. 
Table 4 Selected prospective randomized controlled trials on the effect of oral/enteral vitamin D in adult critically ill patients.

\begin{tabular}{|c|c|c|c|c|}
\hline \multirow[b]{2}{*}{ Author, Journal, Year } & Design & \multirow{2}{*}{$\begin{array}{l}\text { No of } \\
\text { patients }\end{array}$} & \multirow[b]{2}{*}{ Intervention } & \multirow[b]{2}{*}{ Outcomes } \\
\hline & Population & & & \\
\hline \multicolumn{5}{|l|}{ Completed trials } \\
\hline $\begin{array}{l}\text { Amrein K, Critical Care, } \\
2011 \\
\text { Graz, Austria (49) }\end{array}$ & $\begin{array}{l}\text { RCT } \\
\text { Medical ICU, } \\
250 H D<20 \mathrm{ng} / \mathrm{mL}\end{array}$ & 25 & $\begin{array}{l}1 \times 540,000 \mathrm{IU} \mathrm{D}_{3} \\
\text { enteral vs placebo }\end{array}$ & $\begin{array}{l}\text { Normalization of vitamin D levels in most } \\
\text { patients, no adverse events; no difference in } \\
\text { 28-days mortality or length of stay }\end{array}$ \\
\hline $\begin{array}{l}\text { Amrein K, JAMA, } 2014 \\
\text { Graz, Austria (50) }\end{array}$ & $\begin{array}{l}\text { RCT } \\
\text { Mixed ICU, 25OHD } \\
<20 \mathrm{ng} / \mathrm{mL}\end{array}$ & 475 & $\begin{array}{l}1 \times 540,000 \mathrm{IU} \mathrm{D}_{3} \\
\text { enteral, then } \\
5 \times 90,000 \mathrm{IU} \\
\mathrm{D}_{3} / \text { month vs placebo }\end{array}$ & $\begin{array}{l}\text { No difference in hospital length of stay, } \\
\text { overall no significant mortality benefit, but } \\
\text { large and significant mortality benefit in the } \\
\text { predefined subgroup with severe vitamin } D \\
\text { deficiency }(25 \mathrm{OHD})<12\end{array}$ \\
\hline $\begin{array}{l}\text { Quraishi S, Critical Care } \\
\text { Medicine, } 2015 \\
\text { Boston, USA (51) }\end{array}$ & $\begin{array}{l}\text { RCT } \\
\text { ICU, sepsis }\end{array}$ & 30 & $\begin{array}{l}1 \times 200,000 \mathrm{IU} \mathrm{D}_{3} \\
\text { enteral or } \\
1 \times 400,000 \mathrm{IU} \mathrm{D}_{3} \\
\text { enteral vs placebo }\end{array}$ & $\begin{array}{l}\text { Rapid correction of vitamin D deficiency, } \\
\text { increase in LL-37 compared to the placebo } \\
\text { group }\end{array}$ \\
\hline $\begin{array}{l}\text { Han JE, Journal of Clinical } \\
\text { and Translational } \\
\text { Endocrinology, 2016, } \\
\text { Nutrition, } 2017 \\
\text { Atlanta, USA (52) }\end{array}$ & $\begin{array}{l}\text { RCT } \\
\text { ICU, mechanically } \\
\text { ventilated }\end{array}$ & 30 & $\begin{array}{l}5 \times 50,000 \mathrm{IU} \mathrm{D}_{3} \\
\text { enteral or } \\
5 \times 100,000 \mathrm{IU} \mathrm{D}_{3 \prime} \\
\text { enteral vs placebo }\end{array}$ & $\begin{array}{l}\text { Shorter hospital stay, dose dependent } \\
\text { increase of vitamin D levels and increased } \\
\text { hCAP18 mRNA-expression compared to the } \\
\text { placebo group }\end{array}$ \\
\hline $\begin{array}{l}\text { Alizadeh N, International } \\
\text { Journal of Clinical } \\
\text { Practice, } 2016 \\
\text { Teheran, Iran (86) }\end{array}$ & $\begin{array}{l}\text { RCT } \\
\text { Surgical ICU, } \\
\text { stress-induced } \\
\text { hyperglycemia }\end{array}$ & 50 & $\begin{array}{l}600,000 \mathrm{IU} \text { D3, IM vs } \\
\text { placebo }\end{array}$ & $\begin{array}{l}25 \text { OHD levels increased significantly in the } \\
\text { vitamin D group at day 7, fasting plasma } \\
\text { adiponectin levels increased significantly in } \\
\text { the vitamin D group, but not the placebo } \\
\text { group }\end{array}$ \\
\hline $\begin{array}{l}\text { Miroliaee AE, Iranian } \\
\text { Journal of } \\
\text { Pharmaceutical } \\
\text { Research, } 2017 \\
\text { Teheran, Iran (87) }\end{array}$ & $\begin{array}{l}\mathrm{RCT} \\
\mathrm{ICU}, \text { ventilator } \\
\text { associated } \\
\text { pneumonia } \\
250 \mathrm{HD}<30 \mathrm{ng} / \mathrm{mL}\end{array}$ & 46 & $\begin{array}{l}\text { 300,000IU D3, IM vs } \\
\text { placebo }\end{array}$ & $\begin{array}{l}\text { PCT levels significantly lower in the vitamin D } \\
\text { group compared to placebo group, no } \\
\text { significant difference in SOFA score } \\
\text { between groups, mortality rate of patients } \\
\text { in the vitamin D group was significantly } \\
\text { lower than in the placebo group }\end{array}$ \\
\hline
\end{tabular}

\section{Conclusion}

Over the last decade, experimental, observational and clinical studies have highlighted the high prevalence of vitamin D deficiency, and its strong association with morbidity and mortality in critical illness. The scientific rationale as to why this may be the case is compelling.

Supporters of vitamin D do not suggest it to be the panacea but this hormone plays an important pleiotropic role in the setting of critical illness and may support recovery from severe acute illness. We now have a better, albeit not complete understanding from clinical trials of the potential target vitamin D level and dosing strategies required for conferring benefit. Importantly, vitamin D

Table 5 Comparison between the VITDALIZE and the VIOLET trial, the two ongoing, large vitamin D3 intervention trials in acute illness.

\begin{tabular}{|c|c|}
\hline & VITDALIZE (NCT03188796) \\
\hline Where & Europe, multicenter \\
\hline Design & Double-blind, placebo-controlled RCT \\
\hline Sample size & 2400 (one interim analysis at 1200) \\
\hline Intervention & $\begin{array}{l}\text { Loading dose of 540,000 IU vitamin D3 (orally, } \\
\text { enteral) } \\
\text { Daily dose of } 4000 \text { IU vitamin D3 (orally, enteral) } \\
\text { up to day } 90\end{array}$ \\
\hline Inclusion criteria & $\begin{array}{l}25(\mathrm{OH}) \mathrm{D}<12 \mathrm{ng} / \mathrm{mL} \\
\text { Admission to ICU (all-cause) }\end{array}$ \\
\hline Primary endpoint & 28-day-mortality (all-cause) \\
\hline Recruitment started & October 2017 \\
\hline Current status & $\begin{array}{l}\text { Recruiting, estimated completion date } \\
\text { 2021-2022 }\end{array}$ \\
\hline
\end{tabular}

\section{VIOLET (NCT03096314)}

US, multicenter

Double-blind, placebo-controlled RCT

3000 (three interim analyses)

Single dose of 540,000 IU vitamin D3 (orally, enteral)

$25(\mathrm{OH}) \mathrm{D}<20 \mathrm{ng} / \mathrm{mL}$ by point-of-care test

Acute risk factors for ARDS and mortality contributing directly to the need for ICU admission

90-day-mortality (all-cause)

April 2017

Stopped after first interim analysis (July 2018, ca 1400 patients)
๑) 2018 The authors
Published by Bioscientifica Ltd

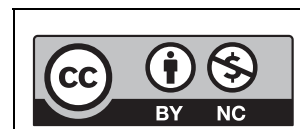

This work is licensed under a Creative Commons Attribution-NonCommercial 4.0 International License. 
testing and supplementation is readily available, safe and inexpensive and could be rapidly implemented into clinical practice if the on-going trials show benefit.

\section{Declaration of interest}

The authors declare that there is no conflict of interest that could be perceived as prejudicing the impartiality of this review.

\section{Funding}

$\mathrm{K}$ A received speaker fees and unrestricted research grants from Fresenius Kabi.

\section{References}

1 Van den Berghe G, Van Roosbroeck D, Vanhove P, Wouters PJ, De Pourcq L \& Bouillon R. Bone turnover in prolonged critical illness: effect of vitamin D. Journal of Clinical Endocrinology and Metabolism 200388 4623-4632. (https://doi.org/10.1210/jc.2003-030358)

2 Lee P, Eisman JA \& Center JR. Vitamin D deficiency in critically ill patients. New England Journal of Medicine. $20093601912-1914$. (https://doi.org/10.1056/NEJMc0809996)

3 McNally JD, Leis K, Matheson LA, Karuananyake C, Sankaran K \& Rosenberg AM. Vitamin D deficiency in young children with severe acute lower respiratory infection. Pediatric Pulmonology 200944 981-988. (https://doi.org/10.1002/ppul.21089)

4 Amrein K, Amrein S, Holl A, Waltensdorfer A, Pieber T \& Dobnig H. Vitamin D, parathyroid hormone and serum calcium levels and their association with hospital mortality in critically ill patients. Critical Care 201014 (Supplement 1) P589. (https://doi.org/10.1186/cc8821)

5 Braun A, Chang D, Mahadevappa K, Gibbons FK, Liu Y, Giovannucci E \& Christopher KB. Association of low serum 25-hydroxyvitamin D levels and mortality in the critically ill. Critical Care Medicine 201139 671-677. (https://doi.org/10.1097/ CCM.0b013e318206ccdf)

6 Perron RM \& Lee P. Efficacy of high-dose vitamin D supplementation in the critically ill patients. Inflammation and Allergy-Drug Targets 201312 273-281. (https://doi.org/10.2174/18715281113129990047)

7 Zajic P \& Amrein K. Vitamin D deficiency in the ICU: a systematic review. Minerva Endocrinologica 201439 275-287.

8 Al-Tarrah K, Hewison M, Moiemen N \& Lord JM. Vitamin D status and its influence on outcomes following major burn injury and critical illness. Burns and Trauma 20186 11. (https://doi.org/10.1186/ s41038-018-0113-4)

9 Rech MA, Colon Hidalgo D, Larson J, Zavala S \& Mosier M. Vitamin D in burn-injured patients. Burns 2018 [epub]. (https://doi. org/10.1016/j.burns.2018.04.015)

10 Amrein K, Christopher KB \& McNally JD. Understanding vitamin D deficiency in intensive care patients. Intensive Care Medicine 201541 1961-1964. (https://doi.org/10.1007/s00134-015-3937-4)

11 Lee P. Vitamin D metabolism and deficiency in critical illness. Best Practice and Research: Clinical Endocrinology and Metabolism 201125 769-781. (https://doi.org/10.1016/j.beem.2011.03.001)

12 Amrein K \& Venkatesh B. Vitamin D and the critically ill patient. Current Opinion in Clinical Nutrition and Metabolic Care 201215 188-193. (https://doi.org/10.1097/MCO.0b013e32834f0027)

13 Amrein K, Zajic P, Schnedl C, Waltensdorfer A, Fruhwald S, Holl A, Purkart T, Wunsch G, Valentin T, Grisold A, et al. Vitamin D status and its association with season, hospital and sepsis mortality in critical illness. Critical Care 201418 R47. (https://doi.org/10.1186/ cc13790)
14 Lucidarme O, Messai E, Mazzoni T, Arcade M \& du Cheyron D. Incidence and risk factors of vitamin D deficiency in critically ill patients: results from a prospective observational study. Intensive Care Medicine 201036 1609-1611. (https://doi.org/10.1007/s00134-0101875-8)

15 McNally JD, Menon K, Chakraborty P, Fisher L, Williams KA, Al-Dirbashi OY \& Doherty DR. The association of vitamin D status with pediatric critical illness. Pediatrics 2012130 429-436. (https:// doi.org/10.1542/peds.2011-3059)

16 Rippel C, South M, Butt WW \& Shekerdemian LS. Vitamin D status in critically ill children. Intensive Care Medicine 201238 2055-2062. (https://doi.org/10.1007/s00134-012-2718-6)

17 Braun AB, Litonjua AA, Moromizato T, Gibbons FK, Giovannucci E \& Christopher KB. Association of low serum 25-hydroxyvitamin D levels and acute kidney injury in the critically ill. Critical Care Medicine 201240 3170-3179. (https://doi.org/10.1097/ CCM.0b013e318260c928)

18 de Haan K, Groeneveld AB, de Geus HR, Egal M \& Struijs A. Vitamin $\mathrm{D}$ deficiency as a risk factor for infection, sepsis and mortality in the critically ill: systematic review and meta-analysis. Critical Care 2014 18 660. (https://doi.org/10.1186/s13054-014-0660-4)

19 Parekh D, Patel JM, Scott A, Lax S, Dancer RC, D'Souza V, Greenwood H, Fraser WD, Gao F, Sapey E, et al. Vitamin D deficiency in human and murine sepsis. Critical Care Medicine. 201745 282-289. (https://doi.org/10.1097/CCM.0000000000002095)

20 Parekh D, Thickett DR \& Turner AM. Vitamin D deficiency and acute lung injury. Inflammation and Allergy-Drug Targets. 201312 253-261. (https://doi.org/10.2174/18715281113129990049)

21 McNally JD, Nama N, O'Hearn K, Sampson M, Amrein K, Iliriani K, McIntyre L, Fergusson D \& Menon K. Vitamin D deficiency in critically ill children: a systematic review and meta-analysis. Critical Care 201721 287. (https://doi.org/10.1186/s13054-017-1875-y)

22 Zhang YP, Wan YD, Sun TW, Kan QC \& Wang LX. Association between vitamin $\mathrm{D}$ deficiency and mortality in critically ill adult patients: a meta-analysis of cohort studies. Critical Care 201418684. (https://doi.org/10.1186/s13054-014-0684-9)

23 Lasky-Su J, Dahlin A, Litonjua AA, Rogers AJ, McGeachie MJ, Baron RM, Gazourian L, Barragan-Bradford D, Fredenburgh LE, Choi AMK, et al. Metabolome alterations in severe critical illness and vitamin D status. Critical Care 201721 193. (https://doi.org/10.1186/ s13054-017-1794-y)

24 Czarnik T, Czarnik A, Gawda R, Gawor M, Piwoda M, Marszalski M, Maj M, Chrzan O, Said R, Rusek-Skora M, et al. Vitamin D kinetics in the acute phase of critical illness: a prospective observational study. Journal of Critical Care 201843 294-299. (https://doi.org/10.1016/j. jcrc.2017.09.179)

25 Nair P, Lee P, Reynolds C, Nguyen ND, Myburgh J, Eisman JA \& Center JR. Significant perturbation of vitamin D-parathyroid-calcium axis and adverse clinical outcomes in critically ill patients. Intensive Care Medicine. 201339 267-274. (https://doi.org/10.1007/s00134012-2713-y)

26 Quraishi SA \& Camargo CA Jr. Vitamin D in acute stress and critical illness. Current Opinion in Clinical Nutrition and Metabolic Care 2012 15 625-634. (https://doi.org/10.1097/MCO.0b013e328358fc2b)

27 De Pascale G \& Quraishi SA. Vitamin D status in critically ill patients: the evidence is now bioavailable! Critical Care 201418 449. (https:// doi.org/10.1186/cc13975)

28 Martucci G, Tuzzolino F, Arcadipane A, Pieber TR, Schnedl C, Urbanic Purkart T, Treiber G \& Amrein K. The effect of high-dose cholecalciferol on bioavailable vitamin $\mathrm{D}$ levels in critically ill patients: a post hoc analysis of the VITdAL-ICU trial. Intensive Care Medicine 201743 1732-1734. (https://doi.org/10.1007/s00134-017-4846-5)

29 Jenkinson C, Taylor AE, Hassan-Smith ZK, Adams JS, Stewart PM, Hewison M \& Keevil BG. High throughput LC-MS/MS method for the simultaneous analysis of multiple vitamin $D$ analytes in serum. Journal of Chromatography: B, Analytical Technologies in the Biomedical 
and Life Sciences 2016 1014 56-63. (https://doi.org/10.1016/j. jchromb.2016.01.049)

30 Prietl B, Treiber G, Pieber TR \& Amrein K. Vitamin D and immune function. Nutrients 20135 2502-2521. (https://doi.org/10.3390/ nu5072502)

31 Rejnmark L, Bislev LS, Cashman KD, Eiriksdottir G, Gaksch M, Grubler M, Grimnes G, Gudnason V, Lips P, Pilz S, et al. Non-skeletal health effects of vitamin D supplementation: a systematic review on findings from meta-analyses summarizing trial data. PLOS ONE 2017 12 e0180512. (https://doi.org/10.1371/journal.pone.0180512)

32 Bouillon R, Carmeliet G, Verlinden L, van Etten E, Verstuyf A, Luderer HF, Lieben L, Mathieu C \& Demay M. Vitamin D and human health: lessons from vitamin $\mathrm{D}$ receptor null mice. Endocrine Reviews 200829 726-776. (https://doi.org/10.1210/er.2008-0004)

33 Campos LT, Brentani H, Roela RA, Katayama ML, Lima L, Rolim CF, Milani C, Folgueira MA \& Brentani MM. Differences in transcriptional effects of 1alpha,25 dihydroxyvitamin D3 on fibroblasts associated to breast carcinomas and from paired normal breast tissues. Journal of Steroid Biochemistry and Molecular Biology 2013133 12-24. (https://doi.org/10.1016/j.jsbmb.2012.08.002)

34 Hewison M. Vitamin D and immune function: an overview. Proceedings of the Nutrition Society 201271 50-61. (https://doi. org/10.1017/S0029665111001650)

35 Dancer RC, Parekh D, Lax S, D'Souza V, Zheng S, Bassford CR, Park D, Bartis DG, Mahida R, Turner AM, et al. Vitamin D deficiency contributes directly to the acute respiratory distress syndrome (ARDS). Thorax 201570 617-624. (https://doi.org/10.1136/ thoraxjnl-2014-206680)

36 Girgis CM, Clifton-Bligh RJ, Hamrick MW, Holick MF \& Gunton JE. The roles of vitamin D in skeletal muscle: form, function, and metabolism. Endocrine Reviews 201334 33-83. (https://doi. org/10.1210/er.2012-1012)

37 Lugg ST, Howells PA \& Thickett DR. Optimal vitamin D supplementation levels for cardiovascular disease protection. Disease Markers 20152015 864370. (https://doi.org/10.1155/2015/864370)

38 Orford N, Cattigan C, Brennan SL, Kotowicz M, Pasco J \& Cooper DJ. The association between critical illness and changes in bone turnover in adults: a systematic review. Osteoporosis International 201425 2335-2346. (https://doi.org/10.1007/s00198-014-2734-1)

39 Orford NR, Bailey M, Bellomo R, Pasco JA, Cattigan C, Elderkin T, Brennan-Olsen SL, Cooper DJ \& Kotowicz MA. The association of time and medications with changes in bone mineral density in the 2 years after critical illness. Critical Care 201721 69. (https://doi. org/10.1186/s13054-017-1657-6)

40 Rousseau AF, Foidart-Desalle M, Ledoux D, Remy C, Croisier JL, Damas P \& Cavalier E. Effects of cholecalciferol supplementation and optimized calcium intakes on vitamin D status, muscle strength and bone health: a one-year pilot randomized controlled trial in adults with severe burns. Burns 201541 317-325. (https://doi. org/10.1016/j.burns.2014.07.005)

41 Orford NR, Lane SE, Bailey M, Pasco JA, Cattigan C, Elderkin T, Brennan-Olsen SL, Bellomo R, Cooper DJ \& Kotowicz MA. Changes in bone mineral density in the year after critical illness. American Journal of Respiratory and Critical Care Medicine 2016193 736-744. (https://doi.org/10.1164/rccm.201508-1514OC)

42 Griffith DM \& Walsh TS. Bone loss during critical illness: a skeleton in the closet for the intensive care unit survivor? Critical Care Medicine 201139 1554-1556. (https://doi.org/10.1097/ CCM.0b013e318215beb4)

43 Grimm G, Vila G, Bieglmayer C, Riedl M, Luger A \& Clodi M. Changes in osteopontin and in biomarkers of bone turnover during human endotoxemia. Bone 201047 388-391. (https://doi. org/10.1016/j.bone.2010.04.602)

44 Schwetz V, Schnedl C, Urbanic-Purkart T, Trummer C, Dimai HP, Fahrleitner-Pammer A, Putz-Bankuti C, Christopher KB, ObermayerPietsch B, Pieber TR, et al. Effect of vitamin D3 on bone turnover markers in critical illness: post hoc analysis from the VITdAL-ICU study. Osteoporosis International 201728 3347-3354. (https://doi. org/10.1007/s00198-017-4190-1)

45 Holick MF, Binkley NC, Bischoff-Ferrari HA, Gordon CM, Hanley DA, Heaney RP, Murad MH \& Weaver CM. Evaluation, treatment, and prevention of vitamin d deficiency: an Endocrine Society Clinical Practice Guideline. Journal of Clinical Endocrinology and Metabolism. 201196 1911-1930. (https://doi.org/10.1210/jc.2011-0385)

46 Ross AC, Manson JE, Abrams SA, Aloia JF, Brannon PM, Clinton SK, Durazo-Arvizu RA, Gallagher JC, Gallo RL, Jones G, et al. The 2011 report on dietary reference intakes for calcium and vitamin D from the Institute of Medicine: what clinicians need to know. Journal of Clinical Endocrinology and Metabolism. 201196 53-58. (https://doi. org/10.1210/jc.2010-2704)

47 Hollander JM \& Mechanick JI. Bisphosphonates and metabolic bone disease in the ICU. Current Opinion in Clinical Nutrition and Metabolic Care 200912 190-195. (https://doi.org/10.1097/ MCO.0b013e328321cda6)

48 Lee P, Ng C, Slattery A, Nair P, Eisman JA \& Center JR. Preadmission bisphosphonate and mortality in critically ill patients. Journal of Clinical Endocrinology and Metabolism 2016101 1945-1953. (https:// doi.org/10.1210/jc.2015-3467)

49 Amrein K, Sourij H, Wagner G, Holl A, Pieber TR, Smolle KH, Stojakovic T, Schnedl C \& Dobnig H. Short-term effects of highdose oral vitamin D3 in critically ill vitamin D deficient patients: a randomized, double-blind, placebo-controlled pilot study. Critical Care 201115 R104. (https://doi.org/10.1186/cc10120)

50 Amrein K, Schnedl C, Holl A, Riedl R, Christopher KB, Pachler C, Urbanic Purkart T, Waltensdorfer A, Munch A, Warnkross H, et al. Effect of high-dose vitamin D3 on hospital length of stay in critically ill patients with vitamin D deficiency: the VITdAL-ICU randomized clinical trial. JAMA 2014312 1520-1530. (https://doi.org/10.1001/ jama.2014.13204)

51 Quraishi SA, De Pascale G, Needleman JS, Nakazawa H, Kaneki M, Bajwa EK, Camargo CA Jr \& Bhan I. Effect of cholecalciferol supplementation on vitamin d status and cathelicidin levels in sepsis: a randomized, placebo-controlled trial. Critical Care Medicine 201543 1928-1937. (https://doi.org/10.1097/CCM.0000000000001148)

52 Han JE, Jones JL, Tangpricha V, Brown MA, Brown LAS, Hao L, Hebbar G, Lee MJ, Liu S, Ziegler TR, et al. High dose vitamin d administration in ventilated intensive care unit patients: a pilot double blind randomized controlled trial. Journal of Clinical and Translational Endocrinology 20164 59-65. (https://doi.org/10.1016/j. jcte.2016.04.004)

53 Holick MF. Vitamin D deficiency. New England Journal of Medicine 2007357 266-281. (https://doi.org/10.1056/NEJMra070553)

54 Sempos CT, Heijboer AC, Bikle DD, Bollerslev J, Bouillon R, Brannon PM, DeLuca HF, Jones G, Munns CF, Bilezikian JP, et al. Vitamin D assays and the definition of hypovitaminosis D: results from the First International Conference on Controversies in Vitamin D. British Journal of Clinical Pharmacology 2018 [epub]. (https://doi. org/10.1111/bcp.13652)

55 Holick MF. The IOM D-lemma. Public Health Nutrition 201114 939-941. (https://doi.org/10.1017/S1368980011000590)

56 Schnedl C, Dobnig H, Quraishi SA, McNally JD \& Amrein K. Native and active vitamin $\mathrm{D}$ in intensive care: who and how we treat is crucially important. American Journal of Respiratory and Critical Care Medicine 2014190 1193-1194. (https://doi.org/10.1164/ rccm.201407-1354LE)

57 McNally JD. Vitamin D as a modifiable risk factor in critical illness: questions and answers provided by observational studies. Journal of Pediatrics 201490 99-101. (https://doi.org/10.1016/j. jped.2013.12.002)

58 Vieth R. Vitamin D toxicity, policy, and science. Journal of Bone and Mineral Research 200722 (Supplement 2) V64-V68. (https://doi. org/10.1359/jbmr.07s221)
This work is licensed under a Creative Commons Attribution-NonCommercial 4.0 International License. 
59 Mata-Granados JM, Vargas-Vasserot J, Ferreiro-Vera C, Luque de Castro MD, Pavon RG \& Quesada Gomez JM. Evaluation of vitamin $\mathrm{D}$ endocrine system (VDES) status and response to treatment of patients in intensive care units (ICUs) using an on-line SPE-LC-MS/ MS method. Journal of Steroid Biochemistry and Molecular Biology 2010 121 452-455. (https://doi.org/10.1016/j.jsbmb.2010.03.078)

60 Nair P, Venkatesh B, Lee P, Kerr S, Hoechter DJ, Dimeski G, Grice J, Myburgh J \& Center JR. A randomized study of a single dose of intramuscular cholecalciferol in critically ill adults. Critical Care Medicine 201543 2313-2320. (https://doi.org/10.1097/ CCM.0000000000001201)

61 Sanders KM, Stuart AL, Williamson EJ, Simpson JA, Kotowicz MA, Young D \& Nicholson GC. Annual high-dose oral vitamin D and falls and fractures in older women: a randomized controlled trial. JAMA 2010303 1815-1822. (https://doi.org/10.1001/jama.2010.594)

62 Jacobs TP, Kaufman M, Jones G, Kumar R, Schlingmann KP, Shapses S \& Bilezikian JP. A lifetime of hypercalcemia and hypercalciuria, finally explained. Journal of Clinical Endocrinology and Metabolism 201499 708-712. (https://doi.org/10.1210/jc.2013-3802)

63 Schlingmann KP, Kaufmann M, Weber S, Irwin A, Goos C, John U, Misselwitz J, Klaus G, Kuwertz-Broking E, Fehrenbach H, et al. Mutations in CYP24A1 and idiopathic infantile hypercalcemia. New England Journal of Medicine 2011365 410-421. (https://doi. org/10.1056/NEJMoa1103864)

64 Scragg R, Khaw KT, Toop L, Sluyter J, Lawes CMM, Waayer D, Giovannucci E \& Camargo CA Jr. Monthly high-dose vitamin D supplementation and cancer risk: a post hoc analysis of the vitamin D assessment randomized clinical trial. JAMA Oncology 2018 e182178. (https://doi.org/10.1001/jamaoncol.2018.2178)

65 Scragg R. Emerging evidence of thresholds for beneficial effects from vitamin D supplementation. Nutrients 201810 E561. (https://doi. org/10.3390/nu10050561)

66 Brenner H, Jansen L, Saum KU, Holleczek B \& Schottker B. Vitamin D supplementation trials aimed at reducing mortality have much higher power when focusing on people with low serum 25-hydroxyvitamin D concentrations. Journal of Nutrition 2017147 1325-1333. (https://doi.org/10.3945/jn.117.250191)

67 Smith H, Anderson F, Raphael H, Maslin P, Crozier S \& Cooper C. Effect of annual intramuscular vitamin D on fracture risk in elderly men and women - a population-based, randomized, double-blind, placebo-controlled trial. Rheumatology 200746 1852-1857. (https:// doi.org/10.1093/rheumatology/kem240)

68 Martineau AR, Jolliffe DA, Hooper RL, Greenberg L, Aloia JF, Bergman P, Dubnov-Raz G, Esposito S, Ganmaa D, Ginde AA, et al. Vitamin D supplementation to prevent acute respiratory tract infections: systematic review and meta-analysis of individual participant data. BMJ 2017356 i6583. (https://doi.org/10.1136/bmj.i6583)

69 Ilahi M, Armas LA \& Heaney RP. Pharmacokinetics of a single, large dose of cholecalciferol. American Journal of Clinical Nutrition $2008 \mathbf{8 7}$ 688-691. (https://doi.org/10.1093/ajcn/87.3.688)

70 Langlois PL, Szwec C, D'Aragon F, Heyland DK \& Manzanares W. Vitamin D supplementation in the critically ill: a systematic review and meta-analysis. Clinical Nutrition 201837 1238-1246. (https://doi. org/10.1016/j.clnu.2017.05.006)

71 Putzu A, Belletti A, Cassina T, Clivio S, Monti G, Zangrillo A \& Landoni G. Vitamin D and outcomes in adult critically ill patients. A systematic review and meta-analysis of randomized trials. Journal of Critical Care 201738 109-114. (https://doi.org/10.1016/j. jcrc.2016.10.029)

72 Weng H, Li JG, Mao Z \& Zeng XT. Randomised trials of vitamin D3 for critically ill patients in adults: systematic review and metaanalysis with trial sequential analysis. Intensive Care Medicine $2017 \mathbf{4 3}$ 277-278. (https://doi.org/10.1007/s00134-016-4591-1)

73 Amrein K, Martucci G \& McNally JD. When not to use metaanalysis: Analysing the meta-analyses on vitamin D in critical care. Clinical Nutrition 201736 1729-1730. (https://doi.org/10.1016/j. clnu.2017.08.009)

74 McNally JD, Ginde AA \& Amrein K. Clarification needed for the systematic review of vitamin D trials in the ICU. Intensive Care Medicine 201743 595-596. (https://doi.org/10.1007/s00134-0164643-6)

75 Venkatram S, Chilimuri S, Adrish M, Salako A, Patel M \& DiazFuentes G. Vitamin D deficiency is associated with mortality in the medical intensive care unit. Critical Care 201115 R292.

76 Higgins DM, Wischmeyer PE, Queensland KM, Sillau SH, Sufit AJ \& Heyland DK. Relationship of vitamin D deficiency to clinical outcomes in critically ill patients. Journal of Parenteral and Enteral Nutrition 201236 713-720. (https://doi. org/10.1177/0148607112444449)

77 Chun RF, Liu PT, Modlin RL, Adams JS \& Hewison M. Impact of vitamin D on immune function: lessons learned from genome-wide analysis. Frontiers Physiology 20145151.

78 Jimenez-Sousa MA, Martinez I, Medrano LM, Fernandez-Rodriguez A \& Resino S. Vitamin D in human immunodeficiency virus infection: influence on immunity and disease. Frontiers Immunology 20189458.

79 Thompson J, Nitiahpapand R, Bhatti P \& Kourliouros A. Vitamin D deficiency and atrial fibrillation. International Journal of Cardiology 2015184 159-162.

80 Kassi E, Adamopoulos C, Basdra EK \& Papavassiliou AG. Role of vitamin D in atherosclerosis. Circulation 2013128 2517-2531.

81 Hassan-Smith ZK, Jenkinson C, Smith DJ, Hernandez I, Morgan SA, Crabtree NJ, et al. 25-hydroxyvitamin D3 and 1,25-dihydroxyvitamin D3 exert distinct effects on human skeletal muscle function and gene expression. PLoS One 201712 e0170665.

82 Gunton JE \& Girgis CM. Vitamin D and muscle. Bone Reports $2018 \mathbf{8}$ 163-167.

83 Amrein K, Fahrleitner-Pammer A \& Dimai HP. Bone - a casualty of ICU survival? Critical Care 201519253.

84 Jurutka PW, Bartik L, Whitfield GK, Mathern DR, Barthel TK, Gurevich M, et al. Vitamin D receptor: key roles in bone mineral pathophysiology, molecular mechanism of action, and novel nutritional ligands. Journal of Bone and Mineral Research 200722 (Suppl 2) V2-V10.

85 Shoback D. Clinical practice. Hypoparathyroidism. New England Journal of Medicine 2008359 391-403.

86 Alizadeh N, Khalili H, Mohammadi M, Abdollahi A \& Ala S. Effect of vitamin D on stress-induced hyperglycaemia and insulin resistance in critically ill patients. International Journal of Clinical Practice 2016 70 396-405.

87 Miroliaee AE, Salamzadeh J, Shokouhi S, Fatemi A, Ardehali SH, Hajiesmaeili MR, et al. Effect of Vitamin D supplementation on procalcitonin as prognostic biomarker in patients with ventilator associated pneumonia complicated with Vitamin D deficiency. Iran Journal of Pharmaceutical Research 201716 1254-1263.

Received in final form 22 September 2018

Accepted 5 October 2018

Accepted Preprint published online 5 October 2018 https://ec.bioscientifica.com https://doi.org/10.1530/EC-18-0184

(c) 2018 The authors Published by Bioscientifica Ltd

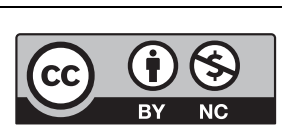

This work is licensed under a Creative Commons Attribution-NonCommercial 4.0 International License. 